\title{
PERBANDINGAN HASIL BELAJAR SISWA DALAM PEMBELAJARAN PKn DENGAN MENGGUNAKAN MODEL PEMBELAJARAN JIGSAW DAN GROUP INVESTIGATION DI KELAS VIII SMP NEGERI I BERGAS KABUPATEN SEMARANG
}

\author{
Nani Mediatati \\ nani.mediatati@staff.uksw.edu \\ Program Studi PPKn \\ FKIP - Universitas Kristen Satya Wacana
}

\begin{abstract}
ABSTRAK
Penelitian ini bertujuan untuk mengetahui ada tidaknya perbedaan yang signifikan hasil belajar siswa dalam pembelajaran PKn dengan menggunakan model pembelajaran jigsaw dan group investigation di kelas VIII SMP Negeri I Bergas semester genap tahun ajaran 2013/2014. Jenis penelitian ini adalah penelitian eksperimen dengan desain eksperimen non equivalent control group design. Desain ini hampir sama dengan pretestpostest control group design, hanya pada desain ini kelompok eksperimen dan kelompok kontrol tidak dipilih secara random. Populasi dari penelitian ini adalah seluruh siswa kelas VIII SMP Negeri I Bergas, sedangkan sampel penelitian diambil kelas VIIIB sebagai kelas eksperimen yang dilakukan pembelajaran menggunakan model jigsaw dan kelas VIIID sebagai kelas kontrol yang dilakukan pembelajaran menggunakan model group investigation.Teknik pengumpulan data menggunakan tes dengan instrument soal pretes dan postes yang telah diuji validitas dan reliabilitasnya untuk mengukur hasil belajar siswa. Teknik analisis data menggunakan uji beda rerata dengan uji independent samplet-test menggunakan bantuan SPSS 16.00 for Windows yang didahului dengan uji normalitas dan uji homogenitas dari sampel. Hasil uji normalitas dan homogenitas menunjukkan bahwa kedua kelas berasal dari populasi yang berdistribusi normal dan mempunyai variansi yang homogen dengan nilai signifikansi lebih dari 5\%. Hasil uji independent sample t-test dari pretes menunjukkan bahwa tidak ada perbedaan hasil belajar awal dari siswa kedua kelas dengan nilai signifikansi 0,849>0,05. Nilai rata-rata kelas eksperimen: 62,42 dan kelas kontrol: 62,79. Sedangkan dari postes menunjukkan adanya perbedaan hasil belajar akhir siswa kedua kelas dengan nilai signifikansi $0,003<0,05$. Nilai rata-rata kelas eksperimen: 81,97 dan kelas kontrol : 76,36. Hasil penelitian ini dapat disimpulkan bahwa ada perbedaan yang signifikan hasil belajar siswa dalam pembelajaran PKn dengan menggunakan model jigsaw dan group investigation di kelas VIII SMP Negeri I Bergas. Hasil belajar siswa dari kelas yang dilakukan pembelajaran menggunakan model jigsaw lebih tinggi dari pada hasil belajar siswa dari kelas yang dilakukan pembelajaran menggunakan model group investigation.
\end{abstract}

Kata Kunci: Model jigsaw, model group investigation, hasil belajar. 


\section{PENDAHULUAN}

Guru merupakan komponen yang sangat penting dalam proses pembelajaran, dan memiliki tanggung jawab serta menentukan dalam pencapaian keberhasilan dari pembelajaran. Sebelum melaksanakan pembelajaran, guru dituntut untuk menyusun rencana pembelajaran, menyiapkan materi yang relevan, merancang model pembelajaran yang disesuaikan dengan situasi dan kondisi siswa, serta menyediakan sumber belajar dan media. Sedangkan dalam pelaksanaan pembelajaran guru dituntut untuk mengembangkan kreatifitas siswa, menciptakan kondisi yang menyenangkan dan menantang, mengembangkan beragam kemampuan, dan menyediakan pengalaman belajar yang beragam. Keberhasilan pembelajaran merupakan pencapaian suatu kompetensi dasar tertentu yang dapat dilihat dari tingkat pemahaman, penguasaan materi, dan prestasi/hasil belajar siswa. Menurut Sagala, (2006:16) hasil belajar siswa yang maksimal dapat diperoleh melalui pemilihan dan penggunaan model pembelajaran oleh guru yang sesuai dengan perkembangan siswa sehingga siswa dapat menemukan konsep dan memahami materi secara optimal. Model pembelajaran adalah kerangka konseptual yang melukiskan prosedur yang sistematis dalam mengorganisasikan pengalaman belajar siswa untuk mencapai tujuan belajar tertentu, dan berfungsi sebagai pedoman bagi guru dalam merencanakan dan melaksanakan aktivitas mengajar. Kemampuan seorang guru dalam memahami dan melaksanakan model pembelajaran yang dipilih sangat berpengaruh terhadap hasil belajar yang dicapai siswa. Ketidaktepatan dalam penggunaan suatu model pembelajaran dapat menimbulkan kebosanan siswa, siswa kurang memahami materi dan siswa cenderung pasif sehingga menimbulkan sikap acuh tak acuh terhadap mata pelajaran. Sesuai dengan pendapat Sugiyanto (2010: 1) bahwa proses belajar mengajar yang berkembang di kelas pada umumnya ditentukan oleh peran guru dan peserta didik sebagai individu-individu yang terlibat langsung di dalam proses pembelajaran. Seorang guru bukanlah hanya mengembangkan ilmu pengetahuan, tetapi lebih kepada kemampuannya melaksanakan pembelajaran yang menarik untuk siswa sehingga siswa lebih aktif mengikuti pembelajaran. Salah satu model pembelajaran yang dapat digunakan guru untuk melibatkan siswa secara aktif dalam pembelajaran adalah model pembelajaran kooperatif. Pembelajaran kooperatif adalah suatu model pembelajaran di mana siswa belajar dan bekerja dalam kelompok-kelompok kecil yang anggotanya 4-6 orang dengan struktur kelompok yang heterogen (Slavin dalam Isjoni, 2009:15). Melalui penerapan model pembelajaran kooperatif memungkinkan siswa untuk dapat berekspresi sesuai dengan kemampuan dan gaya belajar masingmasing, siswa dapat melakukan inisiatifinisiatif untuk bisa menunjukkan kemampuan mereka, bahkan siswa dapat berlatih untuk bekerjasama, memupuk rasa tanggung jawab, serta dapat menjadikan siswa aktif dan tidak hanya sekedar mendengarkan dan menunggu. Ada beberapa macam model pembelajaran kooperatif, diantaranya yaitu group investigation dan jigsaw. Group investigation merupakan model pembelajaran kooperatif yang melibatkan kelompok kecil dimana siswa bekerja menggunakan inquiri kooperatif, perencanaan, proyek dan diskusi kelompok, kemudian mempresentasikan penemuan mereka kepada kelas (Suyatno, 2009: 56). Sedangkan dalam pembelajaran jigsaw, kelas dibagi menjadi 
suatu kelompok kecil yang heterogen yang diberi nama tim jigsaw dan materi dibagi sebanyak kelompok menurut anggota timnya. Tiap-tiap tim diberi satu set materi yang lengkap dan masing-masing individu ditugaskan untuk memilih topik mereka. Kemudian siswa dipisahkan menjadi kelompok ahli atau rekan yang terdiri dari seluruh siswa di kelas yang mempunyai bagian informasi yang sama (Isjoni, 2007:54). Menurut Muhammad Nuh (2013:15) pembelajaran PKn harus dirancang berbasis aktivitas terkait dengan sejumlah tema kewarganegaraan yang diharapkan dapat mendorong peserta didik menjadi warga negara yang baik melalui kepedulian terhadap permasalahan dan tantangan yang dihadapi mayarakat sekitar. Kepedulian tersebut ditunjukkan dalam bentuk partisipasi aktif dalam pengembangan komunitas yang terkait dengan dirinya. Kompetensi yang dihasilkan bukan lagi terbatas pada kajian pengetahuan dan ketrampilan menyajikan hasil kajiannya, tetapi lebih ditekankan pada pembentukan sikap dan tindakan nyata yang harus mampu dilakukan oleh tiap peserta didik. Oleh karena itu model pembelajaran group investigation dan jigsaw ini dianggap tepat diterapkan dalam pembelajaran PKn. Melalui penggunaan model pembelajaran group investigation dan jigsaw diharapkan siswa terlibat aktif dalam pembelajaran melalui kerjasama dan interaksi dengan teman dan guru, sehingga mudah memahami materi pembelajaran dan mencapai hasil belajar yang optimal. Namun demikian, untuk mengetahui mana yang lebih efektif diantara kedua model tersebut terhadap pencapaian hasil belajar siswa, maka dilakukan penelitian eksperimen untuk mengetahui ada tidaknya perbedaan yang signifikan hasil belajar siswa dalam pembelajaran PKn pada standar kompetensi menampilkan perilaku kemerdekaan mengemukakan pendapat dan kompetensi dasar menguraikan pentingnya kemerdekaan mengemukakan pendapat secara bebas dan bertanggung jawab menggunakan model pembelajaran jigsaw dan group investigation di kelas VIII SMP N I Bergas semester genap tahun ajaran 2013/2014.

\section{TINJAUAN PUSTAKA}

\section{Hasil Belajar}

Hasil belajar pada hakekatnya adalah perubahan tingkah laku yang terjadi pada individu setelah mengalami pembelajaran (Sudjana, 2005:3). Perubahan tingkah laku tersebut berupa kemampuan-kemampuan yang dimiliki siswa setelah aktifitas belajar. Menurut Nasution (2006:36) hasil belajar adalah hasil dari suatu interaksi belajar mengajar dan biasanya ditunjukkan dengan nilai tes yang diberikan guru. Hasil belajar dalam pengertian luas dapat mencakup ranah kognitif, afektif, dan psikomotorik. Hasil belajar dalam ranah kognitif menurut Bloom (dalam Anderson dan Krathwohl, 2010:39-43) dibedakan dalam 2 jenis dimensi besar yaitu dimensi pengetahuan, dan dimensi proses kognitif. Dimensi pengetahuan dibedakan dalam empat dimensi yaitu: pengetahuan faktual, konseptual, prosedural dan metakognif, sedangkan dimensi proses kognitif terdiri dari enam dimensi yaitu mengingat (C1), memahami (C2), mengaplikasikan (C3), menganalisis (C4), Mengevaluasi (C5), dan mencipta (C6).

\section{Model Pembelajaran Jigsaw}

Jigsaw adalah salah satu dari model pembelajaran kooperatif yang paling fleksibel (Slavin, 2005:246). Dalam penerapan jigsaw, siswa dibagi berkelompok dengan lima atau enam anggota kelompok 
belajar heterogen. Setiap anggota bertanggung jawab untuk mempelajari, menguasai bagian tertentu bahan yang diberikan kemudian menjelaskan pada anggota kelompoknya. Dengan demikian terdapat rasa saling membutuhkan dan harus bekerjasama secara kooperatif untuk mempelajari materi yang ditugaskan. Para anggota dari kelompok lain yang bertugas mendapat topik yang sama berkumpul dan berdiskusi tentang topik tersebut. Kelompok ini disebut kelompok ahli. Kemudian anggota tim ahli kembali ke kelompok asal dan mengajarkan apa yang telah dipelajarinya dan didiskusikan didalam kelompok ahlinya untuk diajarkan kepada teman kelompoknya sendiri (Ibrahim dkk, 2001:21). Adapun langkah-langkah pelaksanaan jigsaw menurut Aronson dalam Kunandar (2007:365) adalah sebagai berikut:

1. Kelompok asal yaitu:

a. Siswa dibagi ke dalam kelompok kecil 3-6 siswa.

b. Guru memberikan tugas sesuai materi yang diajarkan.

c. Masing-masing siswa dalam kelompok mendapatkan tugas yang berbedabeda dan memahami informasi yang ada didalamnya.

2. Kelompok ahli yaitu:

a. Masing-masing siswa yang memiliki tugas yang sama dikumpulkan dalam satu kelompok sehingga jumlah kelompok ahli sesuai dengan tugas yang telah disiapkan oleh guru.

b. Dalam kelompok ahli ini ditugaskan agar siswa belajar bersama untuk menjadi ahli sesuai dengan tugas yang menjadi tanggung jawabnya.

c. Semua anggota kelompok ahli ditugaskan untuk memahami dan dapat menyampaikan informasi tentang hasil dari tugas yang telah dipahami kepada kelompok asal.

d. Apabila tugas sudah selesai dikerjakan dalam kelompok ahli masingmasing siswa kembali ke kelompok asal.

e. Secara bergiliran masing-masing siswa menyampaikan hasil dari tugas di kelompok ahli.

f. Apabila kelompok sudah menyelesaikan tugasnya secara keseluruhan, masing-masing kelompok melaporkan hasilnya (melakukan presentasi) dan guru memberi klarifikasi.

Menurut Anita Lie (dalam Rusman, 2011:218) pembelajaran dengan model jigsaw ini memungkinkan siswa memiliki banyak kesempatan untuk mengemukakan pendapat dan mengolah informasi yang didapat, dan dapat meningkatkan ketrampilan berkomunikasi. Anggota kelompok bertanggungjawab terhadap keberhasilan kelompoknya dan ketuntasan bagian materi yang dipelajari serta dapat menyampaikan informasinya kepada kelompok lain. Hasil penelitian Jhonson DW dan Jhonson RT (dalam Rusman, 2011:220) tentang model pembelajaran jigsaw menunjukkan bahwa interaksi kooperatif memiliki berbagai pengaruh positif terhadap perkembangan siswa. Pengaruh positif tersebut adalah meningkatkan daya ingat, meningkatkan hubungan antar manusia yang heterogen, meningkatkan ketrampilan hidup bergotong royong, yang dapat digunakan untuk mencapai tarap penalaran tingkat tinggi.

\section{Model Pembelajaran Group Investigation}

Model group investigation merupakan pembelajaran kooperatif yang melibatkan kelompok kecil dimana siswa bekerja menggunakan inquiri kooperatif, perencanaan, proyek dan diskusi kelompok, kemudian 
mempresentasikan hasil diskusi mereka di kelas (Suyatno, 2009: 56). Selanjutnya menurut Eggen dan Kauchak dalam Maimunah (2005: 21) group investigation adalah strategi belajar kooperatif yang menempatkan siswa ke dalam kelompok untuk melakukan investigasi suatu topik. Model group investigation ini melibatkan siswa sejak perencanaan, baik dalam seleksi topik maupun cara mempelajarinya melalui proses investigasi yang mendalam. Model ini menuntut siswa untuk memiliki kemampuan berkomunikasi yang baik maupun dalam ketrampilan proses kelompok (group process skill).

Adapun langkah-langkah pelaksanaan group investigation menurut Hamdani (2010:91) meliputi kegiatan sebagai berikut:

\section{Seleksi topik}

Siswa memilih berbagai sub topik. Selanjutnya siswa diorganisasikan menjadi kelompok-kelompok yang berorientasi pada tugas. Anggota kelompok terdiri atas dua hingga enam orang. Komposisi kelompok heterogen baik dalam jenis kelamin, etnik, maupun kemampuan akademik.

2. Merencanakan kerja sama.

Siswa beserta guru merencanakan tugas yang harus dikerjakan terkait dengan sub topik yang telah dipilih dari seleksi topik (langkah 1).

\section{Implementasi.}

Siswa melaksanakan rencana yang telah dirumuskan pada langkah (2). Pembelajaran harus melibatkan berbagai aktivitas dan ketrampilan dengan variasi yang luas dan mendorong para siswa untuk menggunakan berbagai sumber, baik yang terdapat di dalam maupun di luar sekolah.

\section{Analisis dan sintesis.}

Siswa menganalisis dan mensintesis berbagai informasi yang diperoleh pada langkah (3) dan merencanakan untuk meringkas dan penyajian menarik di depan kelas.

\section{Penyajian hasil akhir.}

Semua kelompok menyajikan presentasi yang menarik dari berbagai topik yang telah dipelajari agar semua siswa dalam kelas saling terlibat dan mencapai suatu perspektif yang luas mengenai topik tersebut. Presentasi kelompok dikoordinasikan oleh guru.

\section{Evaluasi.}

Guru beserta siswa melakukan evaluasi mengenai kontribusi setiap kelompok terhadap pekerjaan kelas sebagai satu keseluruhan. Evaluasi dapat mencakup setiap siswa secara individu atau kelompok atau keduanya.

Menurut Setiawan (2006:9) model group investigation mempunyai kelebihan antara lain (a) memberi semangat kepada siswa untuk berinisiatif, kreatif, dan aktif, (b) meningkatkan rasa percaya diri, (c) siswa dapat belajar untuk memecahkan dan menangani suatu masalah, (d) siswa belajar menghargai pendapat orang lain, dan (e)siswa terlatih untuk mempertanggungjawabkan jawaban yang diberikan.

Hasil penelitian terdahulu yang membandingkan hasil belajar siswa yang diajar menggunakan model pembelajaran jigsaw dan group investigation dalam mata pelajaran tertentu di SMA dan SMP menunjukkan hasil yang berbeda. Hasil penelitian Cici Nadia Putri (2012) menyatakan terdapat perbedaan yang signifikan antara hasil belajar Ekonomi siswa kelas X SMA Negeri 5 Padang dan SMANegeri 2 Gunung Talang yang menggunakan model belajar kooperatif tipe jigsaw dengan group investigation. Hasil belajar Ekonomi siswa yang menggunakan model belajar kooperatif tipe 
jigsaw lebih tinggi dari hasil belajar Ekonomi siswa yang menggunakan pembelajaran group investigation. Sedangkan hasil penelitian Putu Ida Purnamasari dkk. (2012) menyatakan bahwa terdapat perbedaan yang signifikan antara penggunaan model pembelajaran kooperatif tipe group investigation (GI) dengan kooperatif tipe jigsaw terhadap hasil belajar TIK siswa kelas VIII SMP Negeri 5 Singaraja tahun pelajaran 2012/2013. Ratarata post-test hasil belajar TIK pada kelompok Group Investigation (GI) lebih besar dibandingkan dengan kelompok Jigsaw.

\section{METODE PENELITIAN}

Jenis penelitian ini adalah penelitian eksperimen. Penelitian ini menggunakan desain penelitian Quasi Experimental Design dengan bentuk non equivalent control group design (Sugiyono, 2012:116). Dalam desain penelitian ini ada dua kelompok yang dibandingkan yaitu kelas eksperimen dan kelas kontrol. Dua kelas tersebut diberi pretes, kemudian kelas eksperimen diberi perlakuan dengan model pembelajaran jigsaw dan kelas kontrol tidak diberi perlakuan dengan model yang sama tetapi dengan model pembelajaran group investigation, dan terakhir kedua kelas diberi postes.

Desain Penelitian

\begin{tabular}{|c|c|c|c|}
\hline Kel Eksperimen & $\mathrm{O}_{1}$ & $\mathrm{X}$ & $\mathrm{O}_{2}$ \\
\hline Kel Kontrol & $\mathrm{O}_{3}$ & - & $\mathrm{O}_{4}$ \\
\hline
\end{tabular}

Keterangan :

- X : Perlakuan (pembelajaran dengan model jigsaw)

- - : Tidak diberi perlakuan yang sama (pembelajaran dengan model group investigation)

- O1: Pretes kelas eksperimen

- O2: Postes kelas eksperimen

- O3: Pretes kelas kontrol

- O4: Postes kelas kontrol
Populasi dalam penelitian ini adalah siswa kelas VIII SMP N 1 Bergas, Kabupaten Semarang yang terdiri dari 4 kelas yaitu kelas VIIIA, VIIIB, VIIIC, VIIID dengan jumlah siswa 134 orang. Sampel penelitian diambil kelas VIIIB sebagai kelas eksperimen dan kelas VIIID sebagai kelas kontrol. Masing-masing kelas terdiri dari 33 siswa.

Teknik pengumpulan data menggunakan tes. Instrumen pengumpulan data dalam bentuk butir-butir soal tes obyektif pilihan ganda.Uji instrumen meliputi uji validitas dan uji reliabilitas. Butir-butir soal dinyatakan valid apabila nilai dari korelasi item total > 0,3 (Sugiyono, 2012:191). Sedangkan butir-butir soal dinyatakan reliabel apabila nilai $\alpha>0,7$ berdasarkan teknik pengujian Cronbach's Alpha (Suharsimi Arikunto, 2006: 276). Dalam penelitian ini peneliti menggunakan bantuan program SPSS 16.00 untuk menentukan validitas dan reliabilitas butir soal. Dari 40 butir soal yang diuji ada 25 butir soal yang valid. Sedangkan hasil uji reliabilitas didapatkan nilai koefisien reliabilitas $\alpha=0,930$ dengan kategori sangat tinggi/bagus. Berdasarkan hasil uji tersebut menunjukkan bahwa instrumen tes sudah valid dan reliabel sehingga dapat digunakan dalam penelitian.

Teknik analisis data dan uji hipotesis menggunakan uji Independent Sample TTest dengan prasyarat uji normalitas dan homogenitas. Uji normalitas digunakan untuk mengetahui apakah data yang diperoleh berdistribusi normal atau tidak. Sedangkan uji homogenitas digunakan untuk mengetahui keadaan variansi kedua kelompok sama atau berbeda. Uji hipotesis digunakan perhitungan statistik dengan menggunakan uji perbedaan dua rata-rata (uji T) dua sampel yang saling independen. Hipotesis dalam penelitian ini adalah sebagai berikut: 
Ho : Tidak ada perbedaan yang signifikan hasil belajar siswa dalam pembelajaran PKn dengan menggunakan model jigsaw dan model group investigation pada siswa kelas VIII semester genap tahun ajaran 2013/2014 di SMP Negeri 1 Bergas Kabupaten Semarang.

Ha : Ada perbedaan yang signifikan hasil belajar siswa dalam pembelajaran PKn dengan menggunakan model jigsaw dan model group investigation pada siswa kelas VIII semester genap tahun ajaran 2013/2014 di SMP Negeri 1 Bergas Kabupaten Semarang.

\section{HASIL PENELITIAN DAN PEMBAHASAN}

Berdasarkan hasil perhitungan terhadap skor pretes dan postes kelas eksperimen dan kelas kontrol didapatkan nilai hasil uji normalitas KolmogorofSmirnow yang ditunjukkan pada tabel 1 .

Berdasarkan tabel 1 nampak bahwa skor pretes dan postes kelas eksperimen dan kelas kontrol memiliki nilai signifikansi yang lebih besar dari $\alpha=0,05$. Hal ini menunjukkan bahwa data skor pretes dan postes kelas eksperimen dan kelas kontrol berdistribusi normal. Nilai signifikansi pretes kelas eksperimen adalah 0,200>0,05 dan pretes kelas kontrol adalah 0,104>0,05. Sementara itu nilai signifikasi postes kelas eksperimen adalah 0,062>0,05 dan postes kelas kontrol adalah 0,200>0,05.

Selanjutnya hasil uji homogenitas pretes dan postes kelas eksperimen dan kelas kontrol dengan menggunakan Levene Statistik ditunjukkan dalam tabel 2.

Tabel 1 Hasil Uji Normalitas Pretes dan Postes kelas ekpseriman dan kelas kontrol

\begin{tabular}{lcccc}
\hline & \multicolumn{2}{c}{ Pretest } & \multicolumn{2}{c}{ Postes } \\
\hline & $\begin{array}{l}\text { Kelas } \\
\text { Eksp }\end{array}$ & $\begin{array}{c}\text { Kelas } \\
\text { Kontrol }\end{array}$ & $\begin{array}{c}\text { Kelas } \\
\text { Eksp }\end{array}$ & $\begin{array}{c}\text { Kelas } \\
\text { Kontrol }\end{array}$ \\
\hline $\mathrm{N}$ & 33 & 33 & 33 & 33 \\
$\begin{array}{l}\text { Kolmogorov - } \\
\text { Smirnov }\end{array}$ & & & & \\
Sig. (2 -tailed) & 0.125 & 0.139 & 0.149 & 0.116 \\
Sumber: Data primer yang diolah, 2014 & 0.104 & 0.062 & 0.200 \\
\hline
\end{tabular}

Tabel 2 Hasil Uji Homogenitas Pretes dan Postes Kelas Eksperimen dan Kelas Kontrol

\begin{tabular}{lccccc}
\hline & $\begin{array}{c}\text { Levene } \\
\text { Statistik }\end{array}$ & Df1 & Df2 & Signifikasi \\
\hline Pretes kedua kelas & 0.840 & 1 & 64 & 0.773 \\
Postes kedua kelas & 0.656 & 1 & 64 & 0.421 \\
\hline
\end{tabular}

Sumber: Data primer yang diolah, 2014 
Berdasarkan tabel 2 nampak bahwa skor pretes dan postes kelas eksperimen dan kelas kontrol memiliki nilai signifikansinya yang lebih besar dari $\alpha=0,05$. Hal ini menunjukkan bahwa data skor pretes dan postes kelas eksperimen dan kelas kontrol berasal dari varians yang homogen. Nilai signifikansi pretes kelas eksperimen dan kontrol adalah $0,773>0,05$ sedangkan postes kelas eksperimen dan kontrol adalah 0,421>0,05.

Untuk mengetahui apakah kelas eksperimen dan kelas kontrol mempunyai kemampuan awal yang sama atau tidak maka dilakukan uji beda rataan nilai pretes antara kelas eksperimen dan kelas kontrol menggunakan uji $\mathrm{T}$ dengan taraf signifikansi $\alpha=0,05$. Hasil uji $\mathrm{T}$ nilai pretes kelas eksperimen dan kelas kontrol dapat dilihat dalam tabel 3 .
76 dan skor terendah 44. Oleh karena itu tidak ada perbedaan yang signifikan hasil belajar yang menunjukkan kemampuan awal siswa pada kelas eksperimen maupun kelas kontrol.

Langkah selanjutnya adalah uji hipotesis untuk mengetahui ada tidaknya perbedaan hasil belajar siswa antara kedua kelompok kelas yaitu kelas eksperimen dan kelas kontrol setelah diberi perlakuan dengan uji independent sample T-Test. Berikut ini adalah hasil pengujian perbandingan nilai rata-rata kelas eksperimen yang diberi perlakuan dengan model jigsaw dan kelas kontrol yang tidak diberi perlakuan yang sama yaitu dengan model group investigation.

Tabel 3 Uji T nilai pretes kelas eksperimen dan kelas kontrol

Independent Samples Test

\begin{tabular}{llrr}
\hline & & \multicolumn{2}{c}{ pre tes eksperimen_kontrol } \\
\cline { 2 - 3 } & & $\begin{array}{c}\text { Equal variances } \\
\text { assumed }\end{array}$ & $\begin{array}{c}\text { Equal variances } \\
\text { not assumed }\end{array}$ \\
\hline Levene's Test for Equality & F &, 084 \\
of Variances & Sig. &, 773 &,- 191 \\
& T &,- 191 & 63,911 \\
t-test for Equality of & Df & 64 &, 849 \\
Means & Sig. (2-tailed) &, 849 &,- 364 \\
& Mean Difference &,- 364 & 1,902 \\
& Std. Error Difference & 1,902 & $-4,164$ \\
& 95\% Confidence Interval of the & $-4,164$ & 3,437 \\
\hline
\end{tabular}

Dari tabel 3 nampak bahwa hasil uji beda rataan yang diperoleh memiliki nilai signifikansi (2-tailed) sebesar 0,849. Hal ini berarti lebih besar dari nilai $\alpha=0,05$, maka dapat disimpulkan bahwa kelas eksperimen dan kelas kontrol memiliki kemampuan awal yang sama/tidak beda. Perolehan hasil pretes secara keseluruhan menunjukkan bahwa pada kelas eksperimen skor rata-rata sebesar 62,42, skor tertinggi 76 dan skor terendah 44. Sedangkan pada kelas kontrol skor rata-rata sebesar 62,79 , skor tertinggi
Berdasarkan hasil uji yang diperoleh tampak bahwa nilai signifikansi (2-tailed) adalah $0,003<0,05$, maka Ho ditolak dan Ha diterima yang artinya ada perbedaan yang signifikan hasil belajar siswa dalam pembelajaran PKn dengan menggunakan model jigsaw dan model group investigation pada siswa kelas VIII semester genap tahun ajaran 2013/2014 di SMP Negeri 1 Bergas Kabupaten Semarang. Dengan kata lain ada perbedaan yang signifikan antara hasil belajar siswa kelas VIIIB yang diajar dengan 
Tabel 4 Uji T nilai postes kelas eksperimen dan kontrol

Independent Samples Test

\begin{tabular}{|c|c|c|c|c|}
\hline & & & \multicolumn{2}{|c|}{ post test eksperimen kontrol } \\
\hline & & & $\begin{array}{l}\text { Equal variances } \\
\text { assumed }\end{array}$ & $\begin{array}{c}\text { Equal variances } \\
\text { not assumed }\end{array}$ \\
\hline \multirow{5}{*}{$\begin{array}{l}\text { Levene's Test for Equality } \\
\text { of Variances }\end{array}$} & $\mathrm{F}$ & & ,656 & \\
\hline & Sig. & & ,421 & \\
\hline & $\mathrm{T}$ & & 3,073 & 3,073 \\
\hline & Df & & 64 & 62,512 \\
\hline & Sig. (2-tailed) & & ,003 &, 003 \\
\hline \multirow[t]{4}{*}{-test for Equality of Means } & Mean Difference & & 5,333 & 5,333 \\
\hline & Std. Error Difference & & 1,735 & 1,735 \\
\hline & $95 \%$ Confidence Interval of the & Lower & 1,866 & 1,865 \\
\hline & Difference & Upper & 8,800 & 8,802 \\
\hline
\end{tabular}

model pembelajaran jigsaw dan hasil belajar siswa kelas VIIID yang diajar dengan model group investigation. Perolehan hasil postes secara keseluruhan menunjukkan bahwa pada kelas eksperimen yang diajar dengan model jigsaw skor rata-rata sebesar 81,97, skor tertinggi 96 dan skor terendah 72. Sedangkan pada kelas kontrol yang diajar dengan model group investigation skor ratarata sebesar 76,36, skor tertinggi 92 dan skor terendah 64. Hal ini menunjukkan bahwa pembelajaran dengan model jigsaw memberikan hasil yang lebih baik dibandingkan dengan pembelajaran menggunakan model group investigation.

Perbedaan hasil belajar yang signifikan antara kelas eksperimen dengan kelas kontrol ini juga dapat dilihat dari peningkatan rataan hasil belajar siswa baik yang diajar menggunakan model pembelajaran jigsaw maupun model group investigation. Peningkatan rataan hasil belajar siswa yang diajar menggunakan model jigsaw lebih tinggi dibandingkan model group investigation yaitu sebesar 19,55 yang diperoleh dari rataan nilai postes 81,97 dikurangi rataan nilai pretes 62,42 . Sedangkan peningkatan rataan hasil belajar siswa yang diajar menggunakan model group investigation adalah sebesar 13,57 yang diperoleh dari rataan nilai postes 76,36 dikurangi rataan nilai pretes 62,79 . Peningkatan rataan hasil belajar ini menunjukkan peningkatan pemahaman/penguasaan materi pelajaran oleh siswa setelah dilakukan proses pembelajaran. Perbedaan hasil belajar ini bisa terjadi karena proses pembelajaran di kelas eksperimen yang diajar dengan model jigsaw lebih efektif dibandingkan dengan proses pembelajaran dengan model group investigation. Pada saat proses pembelajaran di kelas eksperimen seluruh siswa terlibat aktif dalam memahami/menguasai materi secara individu dan sekaligus mengajarkan kepada orang lain. Jadi setiap siswa memiliki rasa tanggung jawab yang tinggi terhadap pembelajarannya sendiri dan juga pembelajaran orang lain. Sedangkan di kelas kontrol sebagian besar siswa kurang aktif dalam proses pembelajaran karena siswa merasa kesulitan untuk melakukan investigasi dari berbagai sumber untuk menjawab dan menguasai materi pembelajaran yang ditugaskan guru.

\section{KESIMPULAN}

Berdasarkan hasil analisis data dan pembahasan, maka dapat disimpulkan bahwa ada perbedaan yang signifikan hasil belajar siswa dalam pembelajaran PKn dengan menggunakan model pembelajaran 
jigsaw dan group investigation pada siswa kelas VIII semester genap tahun ajaran 2013/ 2014 di SMP Negeri I Bergas. Hal ini terbukti dari hasil perbandingan peningkatan rata-rata hasil post tes antara kelompok eksperimen dan kelompok kontrol yang menunjukkan adanya perbedaan dan hasil analisis uji t yang menunjukkan bahwa perbedaan tersebut signifikan.

\section{SARAN}

Berdasarkan hasil penelitian yang telah dilakukan, maka peneliti memberikan saran berikut ini:

1. Bagi guru, hendaknya guru mempersiapkan secara matang penggunaan model pembelajaran jigsaw dan group investigasi agar proses pembelajaran dapat berjalan secara efektif dan memaksimalkan perannya sebagai fasilitator dan motivator.

2. Bagi sekolah, diharapkan sekolah dapat memilih dan menerapkan model pembelajaran secara tepat sehingga dalam proses pelaksanaan pembelajaran dapat diperoleh hasil belajar siswa yang optimal.

\section{DAFTAR PUSTAKA}

Anderson, L dan Krathwohl, D. 2010. KerangkaLandasan UntukPembelajaran, Pengajaran dan Asesmen Revisi Taksonomi Pendidikan Bloom. Yogyakarta: Pustaka Pelajar.

Arikunto, Suharsimi. 2006. Prosedur Penelitian Suatu Pendekatan Praktek. Yogyakarta: Rineka Cipta.

Cici Nadia Putri. 2012. Perbedaan Hasil Belajar Mata Pelajaran Ekonomi Siswa Antara Penggunaan Model Kooperatif Tipe Jigsaw Dengan Group Investigation Pada Siswa Kelas X SMAN 5 Padang dan SMAN 2 Gunung Talang. Skripsi. Universitas Negeri Padang.
Hamdani. 2010. Strategi Belajar Mengajar. Bandung: CV Pustaka Setia.

Ibrahim, Muslimin, dkk. 2001. Pembelajaran Kooperatif. Surabaya: University Press.

Isjoni, H. 2009. Pembelajaran Kooperatif, Meningkatkan Kecerdasan Komunikasi Antar Peserta Didik, Yogyakarta: Pustaka Pelajar.

Isjoni, H. 2007. Cooperatif Learning. Bandung: Bumi Aksara.

Kunandar. 2007. Guru Profesional. Bandung: Alfabeta.

Maimunah. 2005. Pembelajaran Volume Bola dengan Belajar Kooperatif Metode GI pada Siswa Kelas X SMA Laboratorium UM. Malang: Pascasarjana Universitas Malang.

Muhammmad Nuh. 2013. Pendidikan Pancasila dan Kewarganegaraan. Jakarta: Politeknik Negeri Media Kreatif.

Nasution, S. 2006. Berbagai Pendekatan dalam Proses Belajar Mengajar. Bandung: Bumi Aksara.

Putu Ida Purnamasari, dkk. 2013. Studi Komparasi Pengaruh Penggunaan Model Pembelajaran Kooperatif Tipe Group Investigation (GI) Dengan Kooperatif Tipe Jigsaw Terhadap Aktivitas dan Hasil Belajar TIK (Studi Kasus di kelas VII SMP Negeri 5 Singaraja Tahun Ajaran 2012/2013. KARMAPATI Volume 2, Nomor 5, Juli 2013.

Rusman. 2011. Model-model Pembelajaran. Jakarta: PT Rajagrafindo Persada.

Sagala, Saiful. 2006. Konsep dan Makna Pembelajaran untuk Membantu Memecahkan Problematika Belajar Mengajar. Bandung: Alfabeta. 
Setiawan. 2006. Model Pembelajaran Matematika dengan Pendekatan Investigasi. Yogyakarta: Depdinas PPPG Matematika.

Slavin, Robert E. 2005.Cooperative Learning Teori Riset dan Praktek. Jakarta: Nusamedia.

Sudjana, Nana. 2005. Dasar-Dasar Proses Belajar Mengajar. Bandung: Sinar Baru Algesindo.
Sugiyanto. 2010. Model-Model Pembelajaran Inovatif. Surakarta: Yuma Pustaka.

Sugiyono. 2012. Metode Penelitian Pendidikan (Pendekatan Kuantitatif, Kualitatif, dan $R \& D$ ). Bandung: Alfabeta.

Suyatno. 2009. Pembelajaran Kooperatif dan Inovatif. Surabaya : Media Buana. 